\title{
Benefit and Challenge of Soy Plant-based Formula in Infants and Children \\ of Soy Plant-based Formula in Infants and
}

Received 10 April 2020,

Accepted 24 April 2020

Link to DOI:

10.25220/WNJ.V04.S1.0001

Journal Website:

www.worldnutrijournal.org

\author{
Yvan Vandenplas ${ }^{1}$, Badriul Hegar ${ }^{2}$ \\ 1. Department of Pediatrics, UZ Brussel, Vrije Universiteit Brussel, Belgium \\ 2. Department of Pediatric, Faculty of Medicine, Universitas Indonesia, Clpto Mangunkusumo \\ Hospital, Jakarta, Indonesia
}

\section{Introduction}

The first report of soy being administered to an infant is over 100 years old. ${ }^{1}$ Since the 1960 s the composition of soy formula has been better adapted to the nutritional needs of infants and since 2000 infant formula based on soy fulfils European Directives and legislation for infant feeding.

Soy infant formula contains a soy protein isolate ( $95 \%$ protein), and methionine, carnitine, taurine, iron, calcium phosphor and zinc are added. Heating destroys the anti-protease activity of soy for over $90 \%$. In 2016, soy infant formula was still 12\% of the USA market and $25 \%$ of infants were fed soy infant formula during their first years of life. ${ }^{2}$

In 2006, ESPGHAN published a consensus statement regarding soy infant formula: i) soy protein formula can be used for feeding term infants, but they have no nutritional advantage over cows' milk protein formula and contain high concentrations of phytate, aluminium, and

\begin{tabular}{l} 
Corresponding author: \\
Yvan Vandenplas \\
Department of Paediatrics, UZ Brussel, Vrije \\
Universiteit Brussel, Belgium \\
E-mailaddress: yvan.vandenplas@uzbrussel.be \\
\hline
\end{tabular}

phyto-estrogens (isoflavones), which might have untoward effects; ii) there are no data to support the use of soy protein formulae in preterm infants; iii) indications for soy protein formula include severe persistent lactose intolerance, galactosemia, and ethical considerations (e.g., vegan concepts); iv) soy protein formula have no role in the prevention of allergic diseases and should not be used in infants with food allergy during the first 6 months of life; v) if soy protein formula are considered for therapeutic use in food allergy after the age of 6 months because of their lower cost and better acceptance, tolerance to soy protein should first be established by clinical challenge. ${ }^{3}$ The cut-off age of 6 months was debated and tended to be followed, although based on weak scientific evidence.

According to a review by Katz et al, ${ }^{7}$ based on the information obtained out of 40 studies identified, the established weighted prevalence of soy allergies is 0 to $0.5 \%(0.27)$ for the general population, 0.4 to $3.1 \%$ (1.9) for the referred population, and 0 to $12.9 \%$ (2.7) for allergic children. The prevalence of sensitization after the use of soy infant formula is 8.7 and $8.8 \%$, depending on the method used. ${ }^{7}$ According to this review, there is no difference according to the age of 
6 months. A recently published Mexican consensus paper confirmed the statements of the AAP and concluded that there was no safety issue with soy infant formula. ${ }^{8}$ Soy infant formulas have important advantages in terms of cost-benefit, palatability and effects on the intestinal microbiota, compared to other formulas. ${ }^{8}$ Although evidence to recommend its use in functional digestive disorders is limited, soy infant formulas have an adequate safety profile and are a valid option for infant feeding. ${ }^{8}$

Infants fed soy infant formula have a normal growth. ${ }^{9}$ Lactose-free formula has been recommended in the re-alimentation of an infectious gastroenteritis after failure of lactose-containing realimentation. ${ }^{5}$ Lactose-free re-alimentation results in a decreased need for hospitalization according to data from Thailand. ${ }^{10}$

Anthropometric patterns of children fed soy infant formula are similar to those of children fed cow's milk formula or human milk. ${ }^{11}$ Despite the high levels of phytates and aluminium in soy formula, haemoglobin, serum protein, zinc and calcium concentrations and bone mineral content were found to be similar to those of children fed cow's milk formula or human milk. ${ }^{11}$

Soy formulae used to contain phytates which were blamed for their chelating capacity, preventing the proper absorption of micronutrients. ${ }^{12}$ Today, however, phytates are almost totally removed from the soy formulae. ${ }^{12}$

The levels of genistein and daidzein to be higher in children fed soy infant formula; however, no strong evidence for a negative effect on reproductive and endocrine functions was found. ${ }^{11}$ Immune measurements and neurocognitive parameters were similar in all the feeding groups. ${ }^{11}$ Phyto-estrogens are plant compounds with estrogenic activity. Those contained in soy formula (SF) are of the isoflavone class and include, in order of quantitative and biological importance, genistein, daidzein, and glycitein. ${ }^{13}$ All have a molecular structure quite similar to that of the human female hormone $17-\beta$-oestradiol and, consequently, have estrogenic activity, even if 1,000-10,000 times lower. ${ }^{13}$ They are present in very large amounts in soy formula, although with differences among commercial preparations. It has been calculated that the mean daily intake of isoflavones by an infant exclusively fed with one of the presently marketed soy formula can be as high as $11 \mathrm{mg} / \mathrm{kg}$ body weight, an amount significantly higher than that necessary to exert hormone-like effects in adults. ${ }^{13,14}$ According to other data from literature, the isoflavone intake of an infant fed breastmilk or cow milk formula is $0.005-0.01 \mathrm{mg} / \mathrm{d}$, while with soy infant formula amounts of 6-47 mg/day are reached. ${ }^{15}$ This intake is similar to the daily intake by an adult with a standard Asian diet (8-50 mg/d) or vegan diet (15$60 \mathrm{mg} /$ day), while vegetarians have a lower intake (3-12 mg/day). ${ }^{15}$ A standard Western diet has an isoflavone content of $0.5-3.5 \mathrm{mg} /$ day. ${ }^{15}$

A global evaluation of the impact of modern soy formula on human development seems to suggest that their use is not associated with relevant abnormalities. $^{13}$ The negative influence of isoflavones, which has been repeatedly demonstrated in developing animals, has not been evidenced with the same relevance in humans. Only children with congenital hypothyroidism can have problems and require re-modulation of thyroid hormone replacement doses. The potential harmful effects of soy isoflavones on child development cannot be definitively excluded. ${ }^{13}$ The consumption of soy-based infant formula is not associated with early onset of puberty. ${ }^{16}$ Relative to girls fed with cow-milk formula, those fed with soy formula demonstrated tissue and organ-level developmental trajectories consistent with response to exogenous estrogen exposure. ${ }^{17}$ However, these effects seem to be transitory as no early infant feeding effects were found on reproductive organs volumes and structural characteristics in children age 5 years. ${ }^{18}$

The other concern to take into consideration is the use of transgenic soy in formulas. ${ }^{12}$ The US Department of Agriculture records that up to $93 \%$ of soybean crops are transgenic. ${ }^{12}$ Adverse effects of transgenic soy were never reported.

The addition of fiber offers an additional benefit in infants and young children with constipation. About $10 \%$ of all infants and young children are constipated. ${ }^{19}$ Although all functional gastro-intestinal disorders are considered as separate entities, over $75 \%$ of the infants present with a combination of functional disorders. ${ }^{20}$ Fibers lead to an increase of bowel movements and improve stool consistency. ${ }^{21}$ Fiber has a significantly improved success rate compared to placebo. ${ }^{21}$ Prebiotic oligosaccharides were shown to increase the 
defecation frequency and to soften the stools. ${ }^{22,23}$ The addition of oligo fructose regulates defecation irregularities associated with low fiber intake. ${ }^{24} \mathrm{~A}$ consistent prebiotic effect along with a decrease in $\mathrm{pH}$ and increase in \%-bifidobacteria and \%lactobacilli was found in a group administered $0.4 \mathrm{~g}$ inulin $/ 100 \mathrm{~mL}^{25}$

\section{Conclusion}

Soy infant formula is a valuable alternative for cow milk based infant formula, since nutritional safety and no long-term adverse effects were reported. The supplementation with fiber is effective in the management of constipation.

\section{Conflict of Interest}

Authors declared no conflict of interest regarding this article.

\section{Open Access}

This article is distributed under the terms of the Creative Commons Attribution 4.0 International Licence (http://creativecommons.org/licenses/by/4.0/), which permits unrestricted use, distribution, and reproduction in any medium, provided you give appropriate credit to the original author(s) and the source, provide a link to the Creative Commons license, and indicate if changes were made.

\section{Reference}

1. Rührah J. The soy bean in infant feeding: preliminary report. Arch Pediatr 1909;26:496-501. [Google Scholar]

2. Rossen LM, Simon AE, Herrick KA. Types of infant formulas consumed in the United States. Clin Pediatr (Phila 2016;55:278-85. [Google Scholar]

3. Nutrition, C.o. (ESPGHAN), Agostoni C, Axelsson I, Goulet O, Koletzko B, Michaelsen KF, et al. Soy protein infant formulae and follow-on formulae: a commentary by the ESPGHAN Committee on Nutrition. J Pediatr Gastroenterol Nutr 2006;42:35261. [Google Scholar]
4. Klemola T, Vanto T, Juntunen-Backman K, Kalimo K, Korpela R, Varjonen E. Allergy to soy formula and to extensively hydrolyzed whey formula in infants with cow's milk allergy: a prospective, randomized study with a follow-up to the age of 2 years. J Pediatr 2002;140:219-24. [Google Scholar]

5. Bhatia J, Greer F, Nutrition, A.o.P.C.o. (American) . Use of soy protein-based formulas in infant feeding. Pediatrics 2008;121:1062-8. [Google Scholar]

6. Vandenplas Y, Munasir Z, Hegar B, Kumarawati D, Suryawan A, Kadim M, et al. A perspective on partially hydrolyzed protein infant formula in nonexclusively breastfed infants. Korean journal of pediatrics 2019;62(5):149. [Google Scholar]

7. Katz Y, Gutierrez-Castrellon P, González MG, Rivas $\mathrm{R}$, Lee BW, Alarcon P. A comprehensive review of sensitization and allergy to soy-based products. Clin Rev Allergy Immunol 2014;46:272-81. [Google Scholar]

8. Gutiérrez-Castrellón P, Vázquez-Frías R, JiménezGutiérrez C, González-Rodríguez RY, QuezadaChalita CT, Greenawalt SR, et al. Recomendaciones sobre la utilización de las fórmulas infantiles con proteína aislada de soya en la alimentación del lactante. Documento de posición basado en la evidencia. Gac Med Mex 2019;155. [Google Scholar]

9. Westmark CJ. Soy-based therapeutic baby formulas: testable hypotheses regarding the pros and cons. Front Nutr 2017;3:59. [Google Scholar]

10. Simakachorn N, Tongpenyai Y, Tongtan O, Varavithya W. Randomized, double-blind clinical trial of a lactose-free and a lactose-containing formula in dietary management of acute childhood diarrhea. J Med Assoc Thai 2004;87:641-9. [Google Scholar]

11. Vandenplas Y, Castrellon PG, Rivas R, Gutiérrez CJ, Garcia LD, Jimenez JE, et al. Safety of soya-based infant formulas in children. $\mathrm{Br} J$ Nutr 2014;111:1340-60. [Google Scholar]

12. Verduci E, Elios, S. D' , Cerrato L, Comberiati P, Calvani M, Palazzo S, et al. Cow's milk substitutes for children: nutritional aspects of milk from different mammalian species, special formula and plant-based beverages, special formula and plantbased beverages. Nutrients 2019;11:1739. [Google Scholar]

13. Testa I, Salvatori C, Cara, G. Di, Latini A, Frati F, Troiani S, et al. Soy-based infant formula: are phytoestrogens still in doubt. Front Nutr 2018;5:110. [Google Scholar] 
14. Franke AA, Custer LJ, Tanaka Y. Isoflavones in human breast milk and other biological fluids. Am J Clin Nutr 1998;68:1466. [Google Scholar]

15. Mortensen A, Kulling SE, Schwartz H, Rowland I, Ruefer CE, Rimbach G, et al. Analytical and compositional aspects of isoflavones in food and their biological effects. Mol Nutr Food Res 2009;53. [Google Scholar]

16. Sinai T, Ben-Avraham S, Guelmann-Mizrahi I, Goldberg MR, Naugolni L, Askapa G, et al. Consumption of soy-based infant formula is not associated with early onset of puberty. Eur J Nutr 2019;58:681-87. [Google Scholar]

17. Adgent MA, Umbach DM, Zemel BS, Kelly A, Schall JI, Ford EG, et al. A Longitudinal Study of estrogen-responsive tissues and hormone concentrations in infants fed soy formula. J Clin Endocrinol Metab 2018;103:1899-909. [Google Scholar]

18. Andres A, Moore MB, Linam LE, Casey PH, Cleves MA, Badger TM. Compared with feeding infants breast milk or cow-milk formula, soy formula feeding does not affect subsequent reproductive organ size at 5 years of age. J Nutr 2015;145:871-5. [Google Scholar]

19. Vandenplas Y, Abkari A, Bellaiche M, Benninga M, Chouraqui JP, Çokura F, et al. Prevalence and health outcomes of functional gastrointestinal symptoms in infants from birth to 12 months of age. J Pediatr Gastroenterol Nutr 2015;61:531-7. [Google Scholar]

20. Bellaiche M, Oozeer R, Gerardi - Temporel G, Faure C, Vandenplas Y. Multiple functional gastrointestinal disorders are frequent in formula fed infants and decrease their quality of life. Acta Paediatrica 2018;107(7):1276-82. [Google Scholar]

21. Loening-Baucke V, Miele E, Staiano A. Fiber (glucomannan) is beneficial in the treatment of childhood constipation. Pediatrics. 2004 Mar 1;113(3):e259-64.

22. Bongers ME, Lorijn, F. de , Reitsma JB, Groeneweg M, Taminiau JA, Benninga MA. The clinical effect of a new infant formula in term infants with constipation: a double-blind, randomized cross-over trial. Nutr J 2007;6:8. [Google Scholar]

23. Veereman-Wauters G, Staelens S, Bh, Van de, Plaskie K, Wesling F, Roger LC, et al. Physiological and bifidogenic effects of prebiotic supplements in infant formulae. J Pediatr Gastroenterol Nutr 2011;52(6):763-71. [Google Scholar]

24. Buddington RK, Kapadia C, Neumer F, Theis S. Oligofructose provides laxation for irregularity associated with low fiber intake. Nutrients 2017;9:1372. [Google Scholar]

25. Oswari $\mathrm{H}$, Widodo $\mathrm{AD}$, Handayani $\mathrm{F}$, Juffrie $M$, Sundjaya T, Bindels J, et al. Dosage-related prebiotic effects of inulin in formula-fed infants. Pediatr Gastroenterol Hepatol Nutr 2019;22:63-71. [Google Scholar] 